\title{
Increased milk protein content and whey-to-casein ratio in milk served with breakfast cereal reduce postprandial glycemia in healthy adults: An examination of mechanisms of action
}

\author{
Dalia El Khoury, ${ }^{1}$ Shirley Vien, ${ }^{2}$ Diana Sanchez-Hernandez, ${ }^{2}$ Bonnie Kung, ${ }^{3}$ Amanda Wright, ${ }^{4}$ \\ H. Douglas Goff, ${ }^{3}$ and G. Harvey Anderson ${ }^{2 *}$ \\ ${ }^{1}$ Department of Family Relations and Applied Nutrition, University of Guelph, Guelph, ON, Canada N1G 2W1 \\ ${ }^{2}$ Department of Nutritional Sciences, Faculty of Medicine, University of Toronto, Toronto, ON, Canada M5S 1A8 \\ ${ }^{3}$ Department of Food Science, University of Guelph, Guelph, ON, Canada N1G 2W1 \\ ${ }^{4}$ Department of Human Health \& Nutritional Sciences, University of Guelph, Guelph, ON, Canada N1G 2W1
}

\section{ABSTRACT}

This study describes the effects on glycemic response and the underlying mechanisms of action of increasing the protein concentration and decreasing the casein-towhey ratio in milk when consumed with a high glycemic breakfast cereal. Twelve healthy men and women, aged 18 to $30 \mathrm{yr}$ and with a body mass index of 20 to $24.9 \mathrm{~kg} / \mathrm{m}^{2}$, consumed (in random order) milk beverages $(250 \mathrm{~mL})$ containing either 3.1 or $9.3 \%$ protein and casein-to-whey ratios of either $80: 20$ or 40:60. We measured postprandial appetite, glucose, regulatory hormones, and stomach emptying rate over $200 \mathrm{~min}$, as well as food intake at an ad libitum meal at 120 min. Although pre-meal appetite was suppressed to a greater extent with milk beverages that had high $(9.3 \%)$ compared with regular $(3.1 \%)$ protein content, food intake was similar among all 4 treatments. Premeal mean blood glucose was lower with beverages that had high rather than regular milk protein content, with the lowest glucose peaks after the high milk protein treatment with the 40:60 casein-to-whey ratio. Premeal insulin and C-peptide levels were not affected by milk protein content or casein-to-whey ratio, but pre-meal glucagon-like peptide 1 was higher after the treatment containing high milk protein and the 40:60 casein-to-whey ratio, and pre-meal cholecystokinin was higher after the treatments containing high milk protein content. Plasma paracetamol response was also lower after the treatments containing high compared with regular milk protein content. When consumed with carbohydrate, milk beverages with high protein content and (to a lesser extent) a decreased casein-

Received January 23, 2019.

Accepted April 25, 2019.

*Corresponding author: harvey.anderson@utoronto.ca to-whey ratio lowered postprandial glycemia through insulin-independent mechanisms, primarily associated with delayed stomach emptying.

Key words: milk protein, casein-to-whey ratio, appetite, glycemia, regulatory hormones

\section{INTRODUCTION}

Dietary food patterns are recommended based on associations that show promising benefits for the prevention and management of obesity, type 2 diabetes, and related disorders (Villegas et al., 2007; Erber et al., 2010). Dairy is of interest because its frequent consumption is associated with healthy body weight and lower rates of diabetes (Chen et al., 2014; Hirahatake et al., 2014; Pasiakos, 2015). These benefits are often attributed to the macronutrient content of milk and the unique composition of its proteins (Anderson et al., 2011).

Proteins are known to contribute to the regulation of postprandial glycemia, appetite (Anderson and Moore, 2004; Jahan-Mihan et al., 2011), and body weight (Zemel, 2004). Milk proteins are a heterogeneous group, consisting mainly of casein $(80 \%)$ and whey protein (20\%; Jahan-Mihan et al., 2011). In the gastrointestinal tract, casein and whey proteins and their bioactive peptides affect a number of regulatory functions by interacting with receptors that release hormones, affecting stomach emptying and gastrointestinal nutrient transport and absorption, transmitting neural signals to the brain, and modifying the microflora (Jahan-Mihan et al., 2011). Based on their digestion and absorption rates (measured by the appearance of amino acids in plasma) and their effects on protein synthesis, casein has been referred to as a "slow" protein, and whey as a "fast" protein (Boirie et al., 1997).

The physiological role of dairy proteins starts with their synergistic effects in the gastrointestinal tract (Luhovyy et al., 2007). When consumed alone, whey 
protein lowers post-meal blood glucose (Akhavan et al., 2010), enhances satiety, and reduces food intake (Luhovyy et al., 2007; Akhavan et al., 2010) by both insulin-dependent and insulin-independent mechanisms (Akhavan et al., 2014). Whey protein stimulates a quick release of gut hormones, including glucagon-like peptide 1 (GLP-1), cholecystokinin (CCK), peptide tyrosine-tyrosine (PYY), and glucose-dependent insulinotropic peptide, in parallel to inducing greater satiety effects than casein (Hall et al., 2003). Whey proteins are initially more satiating than casein in people who are normal weight, and in people who are overweight and obese (Hall et al., 2003; Anderson and Moore, 2004; Veldhorst et al., 2009). This finding has been attributed to the clotting properties of casein in the stomach, which slow the rate of digestion and prolong stimulation of gastrointestinal hormones, which in turn slow stomach emptying (Boirie et al., 1997; Dangin et al., 2001; Anderson and Moore, 2004).

Although the physiological characteristics of casein and whey are well described, the physiological significance of their ratio (80:20) and concentration $(3.1 \%$, wt) in cow milk are not. Of note, human milk has a casein-to-whey ratio of 40:60, and a protein content of 1\% (wt; Fox and McSweeney, 1998). Current infant milk formulas often approximate this ratio (Klein, 2002), but are higher in protein (2-2.5\%; Martin et al., 2016). Thus, the introduction of cow milk into a baby's diet leads to a large change in protein ratio and concentration.

Many studies have shown that consumption of cow milk, with the usual protein content of $3.1 \%$ and caseinto-whey ratio of $80: 20$, contributes to reduction in postprandial glycemia, appetite, and food intake (Anderson et al., 2011; Eussen et al., 2016; Law et al., 2017a,b). However, no reports exist on the effects of increasing milk protein content or reducing casein-to-whey ratio on the responses of and associations among glucoregulatory or appetite hormones. The objective of the current study was to describe the effects of milk beverages with increased protein content (9.3 vs. $3.1 \%$ ) and casein-to-whey ratio (40:60 vs. 80:20) when consumed with a high glycemic breakfast cereal on postprandial appetite, food intake, glucose, and regulatory hormones in healthy men and women. We hypothesized that both protein content and casein-to-whey ratio would be factors in the reduction of postprandial glycemia, and that they would do so through insulin-dependent and independent mechanisms.

\section{MATERIALS AND METHODS}

The data reported herein are derived from a subset of 12 of 32 participants in a study focused on the ef- fects of milk-based beverages on subjective appetite, food intake, and postprandial glycemia (Kung et al., 2018). Eligible and interested participants were given the option to choose whether to be part of the subset group. This trial was registered at https://clinicaltrials .gov (clinical trial registry number NCT02471092).

\section{Participants}

Participants were 12 healthy men and women, 18 to $30 \mathrm{yr}$ old, and with a body mass index of 20 to 24.9 $\mathrm{kg} / \mathrm{m}^{2}$. They were recruited through advertisements posted on the University of Guelph campus and surrounding areas (Kung et al., 2018). The University of Guelph Research Ethics Board approved the study protocol before commencement (\#14JN004). We used an initial brief phone screening to assess the eligibility of potential participants. Exclusion criteria consisted of the following: presence of any medical condition, including gastrointestinal disorders; regular medication use (besides hormonal contraceptives); any food allergy, anaphylactic allergy, or both; and smoking or recreational drug use. Elite or training athletes were excluded, along with people trying to lose weight or those whose body weight had changed $>5 \mathrm{~kg}$ in the previous 6 mo. Participants were excluded if they scored $>16$ on the cognitive restraint scale on the three-factor eating questionnaire (Stunkard and Messick, 1985). People who were regularly consuming a high number of caffeinated drinks $(>4 / \mathrm{d})$ or alcoholic drinks $(>14 /$ wk $)$, were taking protein supplements, or who were pregnant or breastfeeding were also excluded. Qualified participants were invited to participate in the study and to read and sign the consent form. Their height and weight were measured and body mass index calculated.

G*Power v 3.1.9.4 software (Faul et al., 2007) was used to calculate the sample size. A minimum of 9 subjects was needed to achieve statistical significance, using an effect size of 0.5 (moderate), at a power level of 0.8 , and $\alpha=0.05$. We decided to recruit 12 participants to account for dropouts (Anderson et al., 2014).

\section{Treatments}

Milk beverages were provided in a repeated-measures design and assigned in random order once per week for all participants (Kung et al., 2018). The 4 milks contained either regular (3.1\%) or high (9.3\%) milk protein concentrations with casein-to-whey ratios of $80: 20$ or $40: 60$. We added whey permeate powder to both $3.1 \%$ milks to standardize their lactose content. The 250-mL drinks were formulated based on skim milk (Neilson Dairy-Saputo Dairy Products Canada G.P., St-Laurent, Quebec, Canada) and whey perme- 
Table 1. Energy and macronutrient nutrient composition for the 4 milk beverages and breakfast cereal (modified from Kung et al., 2018)

\begin{tabular}{|c|c|c|c|c|c|}
\hline Item & $\begin{array}{l}\text { Honey Nut } \\
\text { Cheerios }^{1}\end{array}$ & \multicolumn{4}{|c|}{ Treatment } \\
\hline Calories (kcal) & 232.6 & 200.5 & 201.7 & 253 & 266.5 \\
\hline Available carbohydrate (g) & 42 & 34.7 & 34.7 & 34.7 & 34.7 \\
\hline Protein $(\mathrm{g})$ & 4.6 & 7.9 & 7.9 & 23.3 & 23.4 \\
\hline
\end{tabular}

${ }^{1}$ Provided with all milk treatments (General Mills, Mississauga, ON, Canada).

${ }^{2}$ Skim milk + permeate powder.

${ }^{3}$ Skim milk + permeate powder + water + whey protein concentrate.

${ }^{4}$ Skim milk + skim milk powder.

${ }^{5}$ Skim milk + skim milk powder + whey protein concentrate.

ate (DariSweet 200, \#215503), skim milk powder (Low Temp, \#202001), and whey protein concentrate (Prodel 35. \#33703; all from Parmalat Canada, London, ON, Canada) to increase the concentration of commercial milk protein $(3.1 \%$, wt) 3 -fold $(9.3 \%$, wt) and modify the casein-to-whey protein ratio from normal (80:20) to high whey (i.e., 40:60), while holding the lactose (34.7 g) content constant (Table 1). The beverages were cold-mixed and served chilled (at a volume of $250 \mathrm{~mL}$ ) with $58 \mathrm{~g}$ of Honey Nut Cheerios (General Mills, Mississauga, ON, Canada) and $100 \mathrm{~mL}$ of water, and consumed by participants in isolation at a constant pace within 5 min. All breakfast meals were standardized to provide a total available carbohydrate content of 76.7 $\mathrm{g}$, approximating $48 \mathrm{~g}$ of glucose provided from oat flour $(21.2 \mathrm{~g})$, sucrose $(18 \mathrm{~g})$, and lactose $(34.7 \mathrm{~g})$. We added $1.5 \mathrm{~g}$ of crushed acetaminophen (Tylenol; McNeil Consumer Healthcare, Markham, ON, Canada) to each $250 \mathrm{~mL}$ serving of the breakfast meal to measure plasma paracetamol as a marker of gastric emptying.

\section{Protocol}

We used a double-blinded, controlled, crossover randomized design (Kung et al., 2018). Participants were assigned each of the 4 treatments in random order and allocated 3-digit number coded treatments at study visits separated by $1 \mathrm{wk}$. Experimental sessions took place at the Human Nutraceutical Research Unit at the University of Guelph (Guelph, ON, Canada). As in previous studies, participants were asked not to consume any food within $12 \mathrm{~h}$ but were allowed to drink water until $1 \mathrm{~h}$ before their session (Panahi et al., 2013a; El Khoury et al., 2014a; Panahi et al., 2014). Each participant arrived at the same chosen time for each session to minimize within-subject variability. Participants were instructed to refrain from alcohol consumption and any unusual exercise or activity $24 \mathrm{~h}$ before the study sessions. They also completed a 24 -h food recall and were asked to eat according to their recall the day before each study visit.

To ensure that instructions were followed, participants filled out a questionnaire about sleep habits and stress factors (Kung et al., 2018). Participants who indicated feelings of illness, atypical sleep, or stress were asked to reschedule. Baseline fingerprick blood samples for glucose concentration were obtained in duplicate and analyzed using a glucose meter (Glucose 201+ Analyzer; HemoCue, Angelholm, Sweden). If participants reported significant deviations from their usual patterns, or if their fasting blood glucose was above 5.5 $\mathrm{mmol} / \mathrm{L}$, sessions were rescheduled.

At the beginning of each session, satiety visual analog scale (VAS) questionnaires and finger prick samples (for the analysis of blood glucose) were obtained and an indwelling intravenous catheter was placed in an antecubital vein by a phlebotomist. Immediately after, participants were given the treatment and asked to consume it within $5 \mathrm{~min}$. They then completed a palatability VAS (at 5 min; El Khoury et al., 2014a,b) and continued to do so at 15-min intervals concurrently before fingerprick blood samples at 15- to 30-min intervals thereafter (i.e., 0, 15, 30, 45, 60, 90, 120, 140, 155, 170, 185, $200 \mathrm{~min})$. Venous blood samples were collected at 30, 60, and 120 min before consumption of an ad libitum pizza lunch meal, and then at 140, 170, and 200 min after consumption of the lunch meal. Gastrointestinal discomfort was measured using VAS.

At $120 \mathrm{~min}$, participants, in isolation, were served an ad libitum pizza lunch and instructed to eat until comfortably full. The four-cheese 13-cm pizzas (McCain Foods, Florenceville, NB, Canada) were prepared by baking in an oven at $425^{\circ} \mathrm{F}$ for $10 \mathrm{~min}$. Pizzas were cut into quarters, and 4 pizzas were served (approximately 
$81 \mathrm{~g} /$ plate) on each tray and served with a 500-mL glass of cool water. Participants were given 6 to $7 \mathrm{~min}$ with each tray, and up to 3 trays were presented during a maximum total lunch period of $20 \mathrm{~min}$. The pizza and water were weighed before and after serving to determine food and energy intakes, which were calculated based on the product label nutritional information. Satiety, blood glucose, and gastrointestinal hormone measurements continued for $1 \mathrm{~h}$ after the pizza lunch meal (i.e., at 140, 155, 170, 185, and $200 \mathrm{~min}$ ).

Satiety was measured using a $100-\mathrm{mm}$ VAS self-reported paper questionnaire, with hunger, fullness, desire to eat, and prospective food consumption horizontal anchored scales (i.e., not at all hungry versus extremely hungry; Poortvliet et al., 2007). Appetite score was calculated based on the average of individual scales: [hunger $+(100-$ fullness $)+$ desire to eat + prospective food consumption]/4. Participants were also asked to complete questionnaires related to the palatability of the breakfast and lunch meals, and gastrointestinal symptoms during the 24-h period following each study visit, using an anchored 100-mm horizontal VAS (Guyonnet et al., 2013).

\section{Blood Parameters}

Blood was collected in $8.5-\mathrm{mL}$ BD P800 tubes (BD Diagnostics, Franklin Lakes, NJ), containing spraydried $\mathrm{K}_{2}$ EDTA anticoagulant and proprietary additives, which include dipeptidyl peptidase IV, esterase, and other protease inhibitors to prevent the proteolytic breakdown of hormones. The tubes were centrifuged at $1,300 \times g$ for $20 \mathrm{~min}$ at $4^{\circ} \mathrm{C}$. Collected plasma samples were aliquoted in Eppendorf tubes and stored at $-80^{\circ} \mathrm{C}$ for analyses. Blood glucose and plasma concentrations of insulin, active GLP-1, active ghrelin, PYY, CCK, C-peptide, and paracetamol (acetaminophen) were measured. Glucose was measured through fingerprick blood and a blood glucose meter (Glucose 201+Analyzer; HemoCue). We used ELISA kits (ALPCO, Salem, NH; Cambridge Life Sciences, Cambridgeshire, UK; Millipore, Billerica, MA; Phoenix Pharmaceuticals Inc., Burlingame, CA) to measure insulin [intra-assay coefficient of variation $(\mathbf{C V})<4 \%$; inter-assay $\mathrm{CV}<$ 5\%; cat. no. 80-INSHU-E01.1, E10.1; ALPCO], active GLP-1 (intra-assay CV $<5 \%$; inter-assay CV $<1 \%$; cat. no. EGLP-35K; Millipore), active ghrelin (intra-assay $\mathrm{CV}<5 \%$; inter-assay CV $<5 \%$; cat. no. EZGRA-88K; Millipore), total PYY (intra-assay $\mathrm{CV}<3 \%$; interassay CV $<3 \%$; cat. no. EZHPYYT66K; Millipore), CCK (intra-assay $\mathrm{CV}<4 \%$; inter-assay $\mathrm{CV}<7 \%$; cat. no. EKE-069-04; Phoenix Pharmaceuticals Inc., Burlingame, CA), C-peptide (intra-assay $\mathrm{CV}<4 \%$; interassay CV $<4 \%$; cat. no. 80-CPTHU-E01.1; Millipore) and paracetamol (cat. no. K5055.02; Cambridge Life Sciences, Cambridgeshire, UK). These biomarkers were measured at the Department of Nutritional Sciences, University of Toronto, Toronto, ON, Canada.

\section{Data and Statistical Analyses}

SAS version 9.4 (SAS Institute Inc., Cary, NC) was used for all statistical analyses. The data analyzed in this study were a subset of data published previously (Kung et al., 2018). A priori, we decided to analyze only the 4 protein treatments and exclude the permeate (no protein) treatment reported in the previous study (Kung et al., 2018) to determine the effect of protein concentration (regular $3.1 \%$ vs. high $9.3 \%$ ) and caseinto-whey ratio (80:20 vs. 40:60). Therefore, the source of variation was divided into 4 components: variability due to concentration, variability due to ratio, variability due to the interaction between concentration and ratio, and residual variation. All analyses initially included sex as a factor, but results were pooled when we found no significant sex effect or interactions.

Three-factor ANOVA was followed by Tukey's post hoc test using SAS PROC MIXED procedure to analyze the effects of protein concentration, protein ratio, sex, and their interaction on food intake [pizza (kcal)] and total food intake [pizza (kcal) + breakfast (kcal)]. Three-factor repeated-measures analysis of covariance (ANCOVA) followed by Tukey's post hoc test in the SAS PROC MIXED procedure to analyze appetite, glucose, insulin, GLP-1, PYY, ghrelin, C-peptide, CCK, and paracetamol concentrations during the pre-meal period (0-120 min), with baseline (0 min) as a covariate. We applied 3-factor repeated-measures ANOVA to describe treatments effect on absolute plasma concentrations over the post-meal period (140-200 min). When we found a significant interaction between time and protein concentration or time and protein ratio, we performed a 1-way ANOVA at all time points.

Pearson correlation coefficients were used to detect associations among the means, in the pre and postmeal periods, for all dependent variables. All data were checked for normality. When data were not normally distributed, SAS PROC GLIMMIX for all ANCOVA, ANOVA, and Spearman rank-order for correlations were conducted. Significance was set at $P \leq 0.05$.

\section{RESULTS}

\section{Participants}

Twelve participants completed the study: 6 men and 6 women. Characteristics of the 12 participants were as follows (mean \pm standard error of the mean): age 
Table 2. Mean \pm SEM baseline characteristics of participants

\begin{tabular}{lcc}
\hline Characteristic & Women $(\mathrm{n}=6)$ & Men $(\mathrm{n}=6)$ \\
\hline Age $(\mathrm{yr})$ & $22.5 \pm 1.4$ & $23.2 \pm 1.2$ \\
Weight $(\mathrm{kg})$ & $62.0 \pm 3.2$ & $78.1 \pm 3.2^{*}$ \\
Height $(\mathrm{m})$ & $1.7 \pm 0.04$ & $1.8 \pm 0.02^{*}$ \\
Body mass index $\left(\mathrm{kg} / \mathrm{m}^{2}\right)$ & $22.3 \pm 0.9$ & $24.1 \pm 1.3$ \\
Waist circumference $(\mathrm{cm})$ & $74.7 \pm 3.4$ & $84.0 \pm 2.8$ \\
Blood pressure $(\mathrm{mm} \mathrm{Hg}$; systolic/diastolic) & $116.8 \pm 2.9 / 70.6 \pm 4.6$ & $132.3 \pm 6.1^{*} / 72.1 \pm 3.9$ \\
Fasting blood glucose $(\mathrm{mmol} / \mathrm{L})$ & $5.0 \pm 0.2$ & $5.1 \pm 0.1$ \\
\hline
\end{tabular}

*Significantly different from women, $P<0.05$.

$22.8 \pm 3.0$ yr; BW $70.0 \pm 11.21 \mathrm{~kg}$; height $1.7 \pm 0.1 \mathrm{~m} ;$ body mass index $23.2 \pm 2.7 \mathrm{~kg} / \mathrm{m}^{2}$; waist circumference $79.3 \pm 8.7 \mathrm{~cm}$; blood pressure $124.5 \pm 13.8 / 71.33 \pm$ $10.0 \mathrm{~mm} \mathrm{Hg}$; fasting blood glucose $5.0 \pm 0.4 \mathrm{mmol} / \mathrm{L}$. A summary of the baseline characteristics is shown in Table 2. Men had significantly higher BW, height, and systolic blood pressure at baseline than women $(P<$ $0.05)$.

\section{Food Intake}

Food intake [pizza (kcal)] and total food intake [pizza $(\mathrm{kcal})+$ breakfast $(\mathrm{kcal})]$ were similar after all 4 treatments (Table 3). However, caloric intakes were higher in men than in women from the pizza meal alone and from the pizza and breakfast meals combined $(P=0.0005)$.

\section{Subjective Appetite}

In the pre-meal period, appetite was affected by time $(P<0.0001)$ and high milk protein concentration. Higher appetite (less satiety) scores were reported after high (vs. regular) milk protein treatments $(P=0.0263$; Figure 1). However, we observed no differences by milk protein concentration or ratio during the post-meal period (Table 4).

\section{Blood Glucose}

Premeal blood glucose was affected by time $(P<$ $0.0001)$, milk protein concentration $(P=0.0022)$, ratio $(P=0.0409)$, and concentration $\times$ time interaction $(P=0.0306$; Figure 2). Pre-meal mean blood glucose was lower after the high versus the regular milk protein treatments. These effects can be explained by differences observed at 30 and $45 \mathrm{~min}$. Blood glucose peaked at $30 \mathrm{~min}$ after all treatments but was lowest after the high milk protein treatment with the 40:60 ratio. Blood glucose remained lower for only the high milk protein with 40:60 ratio treatment at 45 min, compared with the regular milk protein with the 80:20 ratio (Figure $2)$. In the post-meal period, blood glucose was affected only by time $(P=0.0030)$.

\section{Plasma Insulin}

Pre-meal plasma insulin concentration was affected by time $(P<0.0001)$, but not by milk protein concentration or ratio (Table 4). Pre-meal insulin was significantly higher in female than in male participants (47.8 \pm 4.2 vs. $29.5 \pm 4.2 \mu \mathrm{IU} / \mathrm{mL}, P=0.0112$ ). Post-meal insulin was increased by meal consumption, but was only affected by time post-meal $(P=0.0065)$.

Table 3. Mean \pm SEM food intake $(\mathrm{n}=12)$

\begin{tabular}{llcc}
\hline Sex & Treatment & $\begin{array}{c}\text { Pizza }^{1} \\
\text { intake }^{1}(\mathrm{kcal})\end{array}$ & $\begin{array}{c}\text { Total food } \\
\text { intake }^{2} \text { (kcal) }\end{array}$ \\
\hline Female & $3.1 \%$ milk protein (80:20) & $451.81 \pm 78.80$ & $884.91 \pm 78.80$ \\
& $3.1 \%$ milk protein (40:60) & $464.86 \pm 67.65$ & $898.96 \pm 67.65$ \\
& $9.3 \%$ milk protein (80:20) & $431.42 \pm 77.12$ & $917.02 \pm 77.12$ \\
Male & $9.3 \%$ milk protein (40:60) & $376.41 \pm 80.46$ & $875.51 \pm 80.46$ \\
& $3.1 \%$ milk protein (80:20) & $963.78 \pm 99.46$ & $1,396.88 \pm 99.46$ \\
& $3.1 \%$ milk protein (40:60) & $1,053.38 \pm 90.15$ & $1,487.48 \pm 90.15$ \\
& $9.3 \%$ milk protein (80:20) & $1,096.54 \pm 108.79$ & $1,582.14 \pm 108.79$ \\
& $9.3 \%$ milk protein (40:60) & $1,037.64 \pm 130.21$ & $1,536.74 \pm 130.21$ \\
\hline
\end{tabular}

${ }^{1}$ Effect of treatments on pizza intake (kcal). Concentration, $P=0.9509$; ratio, $P=0.9423$; sex, $P=0.0005$; concentration $\times$ ratio, $P=0.0981$; by 3 -way ANOVA.

${ }^{2}$ Effect of treatments on total food intake [pizza (kcal) + breakfast (kcal)]. Concentration, $P=0.0901$; ratio, $P=0.9094$; sex,$P=0.0005$; concentration $\times$ ratio, $P=0.1377$; by 3 -way ANOVA. 


\section{Plasma C-peptide}

Pre-meal plasma C-peptide concentrations were affected by time $(P<0.0001)$, but not by milk protein concentration or ratio (Table 4 ). Pre-meal C-peptide was higher in female than in male participants (1070.8 \pm 99.6 vs. $722.7 \pm 99.6 \mathrm{pmol} / \mathrm{L}, P=0.0345)$. Postmeal plasma $\mathrm{C}$-peptide was affected only by caseinto-whey ratio: $\mathrm{C}$-peptide was higher after treatments containing the 40:60 compared with the 80:20 ratio $(1377.1 \pm 214.2$ vs. $1243.5 \pm 214.2, P=0.0147$; Figure 3$)$.

\section{Plasma GLP-1}

Pre-meal plasma GLP-1 was affected by time $(P<$ $0.0001)$, milk protein concentration $(P=0.0075)$, and ratio $(P=0.0245$; Figure 4$)$. It was higher after treatments containing high milk protein and the 40:60 ratio compared with treatments containing regular milk protein concentration and the $80: 20$ ratio $(P=0.0081)$. Post-meal GLP-1 was affected by time $(P=0.0001)$, but not by milk protein concentration or ratio.

\section{Plasma PYY}

Pre-meal PYY concentrations were affected only by time $(P<0.0001)$. In the post-meal period, PYY was affected only by sex: PYY was greater in male than in female participants $(160.8 \pm 7.6$ vs. $134.7 \pm 7.6 \mathrm{pg} / \mathrm{mL}$, $P=0.0363)$.

\section{Plasma CCK}

Pre-meal CCK concentrations were affected by time $(P<0.0001)$, milk protein concentration, and sex. Premeal CCK was greater after the high versus the regular milk protein treatments $(0.219 \pm 0.004$ vs. $0.210 \pm$ $0.004 \mathrm{ng} / \mathrm{mL}, P=0.0443$, Figure 5) and greater in female than male participants $(0.226 \pm 0.005$ vs. 0.203 $\pm 0.005 \mathrm{ng} / \mathrm{mL}, P=0.0066)$. A milk protein concentration $\times$ sex interaction was also significant. The interaction can be explained by higher plasma concentrations in female participants after treatments containing high versus regular milk protein $(P=0.0201)$, but responses were similar in their male counterparts after both treatments. Post-meal CCK did not reveal any differences.

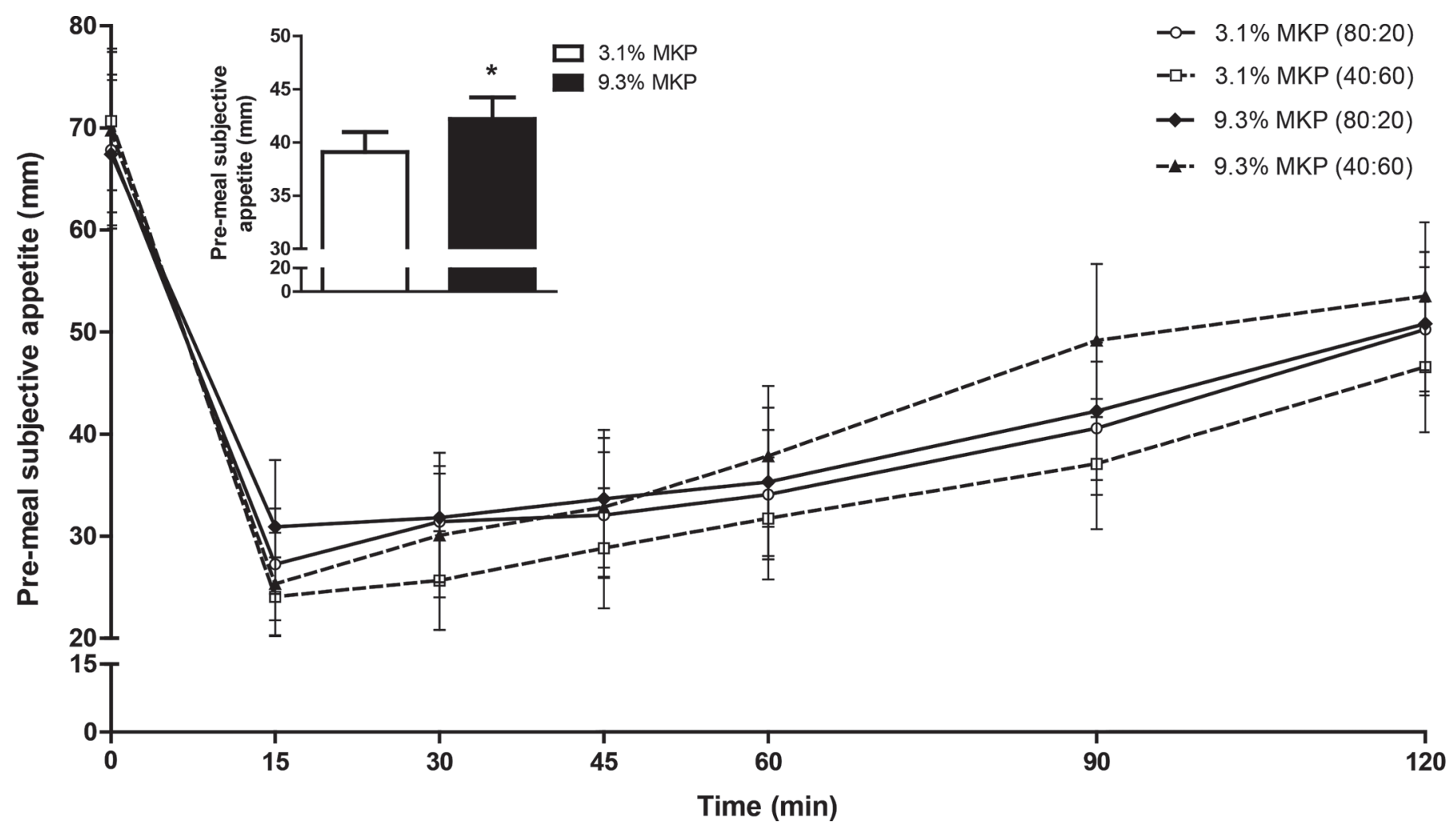

Figure 1. Effect of treatments, 3.1\% milk protein (MKP) (80 casein:20 whey protein), 3.1\% MKP (40 casein:60 whey protein), 9.3\% MKP (80 casein:20 whey protein), and 9.3\% MKP (40 casein:60 whey protein), on pre-meal appetite (measured in millimeters on a visual analog scale) over time, from 0 to $120 \mathrm{~min}$, after the consumption of a breakfast meal and just before the consumption of the ad libitum pizza lunch in healthy adults.. Concentration, $P=0.0263$; ratio, $P=0.3469$; time, $P<0.0001$; concentration $\times$ ratio, $P=0.2452$; concentration $\times$ time, $P=$ 0.7365 ; ratio $\times$ time, $P=0.7295$, by 3 -way analysis of covariance. All values are mean $\pm \mathrm{SEM}, \mathrm{n}=12$. Embedded panel shows mean appetite suppression by concentration of MKP. *An asterisk indicates a statistically significant difference between treatments of different MKP. 


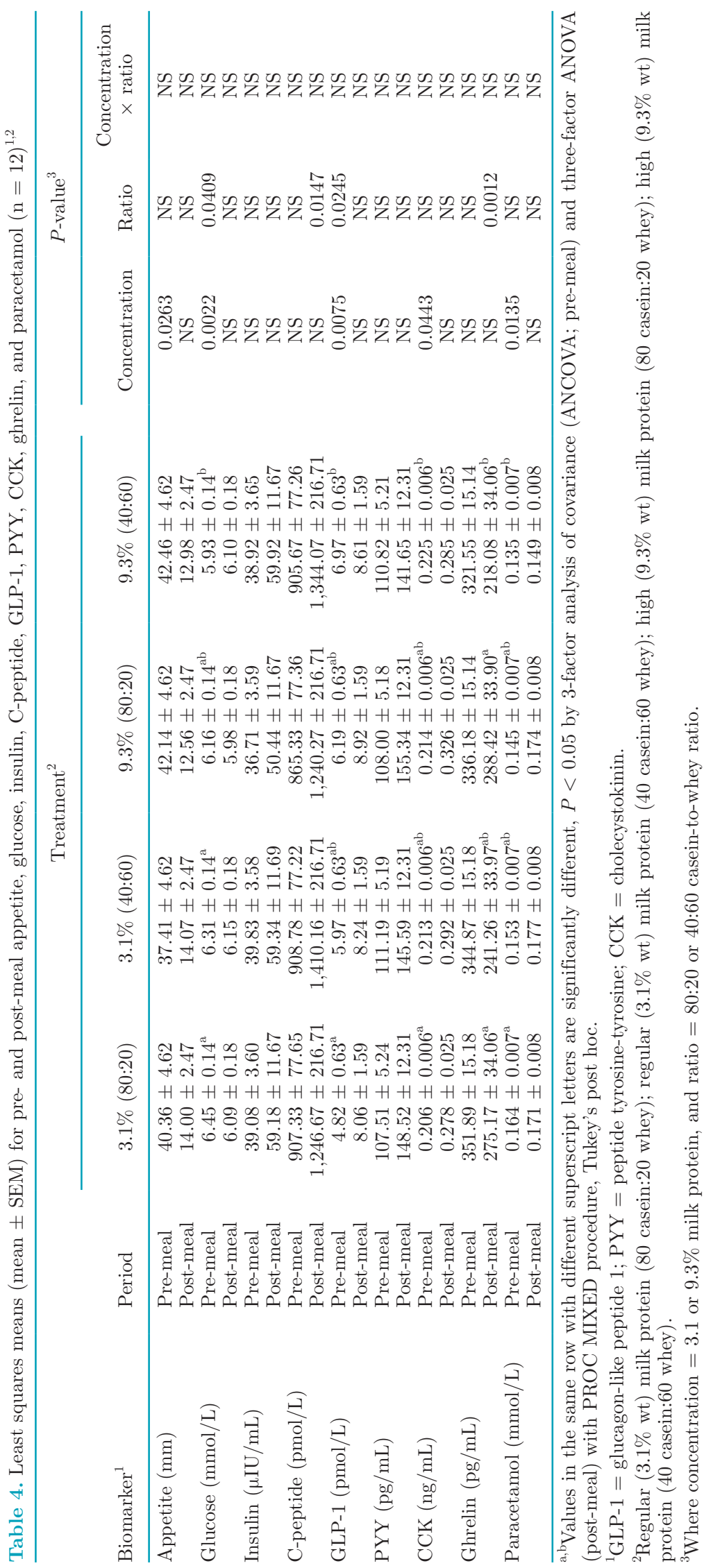




\section{Plasma Ghrelin}

Pre-meal ghrelin concentrations were affected by time $(P<0.0001)$. We observed an interaction between milk protein ratio and time $(P=0.0388$, Figure 6$)$, but no main effect of ratio. At $120 \mathrm{~min}$, ghrelin was suppressed more after treatments containing the 40:60 versus the 80:20 casein-to-whey ratio $(280.39 \pm 20.35$ vs. $336.41 \pm 20.35 \mathrm{pg} / \mathrm{mL}, P=0.0078$, Figure 7$)$. Postmeal ghrelin concentrations were affected by time $(P=$ 0.0012 ) and milk protein ratio; ghrelin was suppressed more after treatments containing the 40:60 versus the 80:20 casein-to-whey ratio $(P=0.0012$, Table 4$)$.

\section{Plasma Paracetamol}

Pre-meal paracetamol concentrations were affected by time $(P<0.0001)$ and milk protein concentration $(P=0.0135$, Table 4). Plasma paracetamol response was lower after the treatments containing high versus regular milk protein (Figure 5). The post-meal period did not reveal any differences.

\section{Correlations}

Correlations between pre-meal means (Table 5) showed that subjective appetite was negatively associated with insulin $(\mathrm{r}=-0.36)$. Glucose was negatively associated with GLP-1 $(\mathrm{r}=-0.32)$. Insulin was positively associated with C-peptide $(\mathrm{r}=0.60)$ and CCK $(\mathrm{r}=0.31)$, but negatively associated with ghrelin $(\mathrm{r}$ $=-0.57)$ and paracetamol $(\mathrm{r}=-0.32)$. As well, Cpeptide was positively correlated with CCK $(\mathrm{r}=0.40)$, GLP-1 was positively correlated with PYY $(\mathrm{r}=0.32)$, and CCK was negatively associated with paracetamol $(\mathrm{r}=-0.30)$.

For the post-meal means (Table 5), subjective appetite was positively associated with glucose $(\mathrm{r}=0.32)$, insulin $(\mathrm{r}=0.38)$, and GLP-1 $(\mathrm{r}=0.54)$. Glucose was positively associated with insulin $(\mathrm{r}=0.63)$ and C-peptide $(\mathrm{r}=0.54)$, but negatively associated with ghrelin $(\mathrm{r}=-0.39)$. Insulin was positively associated with C-peptide $(r=0.67)$ and CCK $(r=0.40)$, but negatively associated with ghrelin $(\mathrm{r}=-0.31)$, and Cpeptide was positively correlated with CCK $(\mathrm{r}=0.58)$ but negatively associated with ghrelin $(\mathrm{r}=-0.33)$.

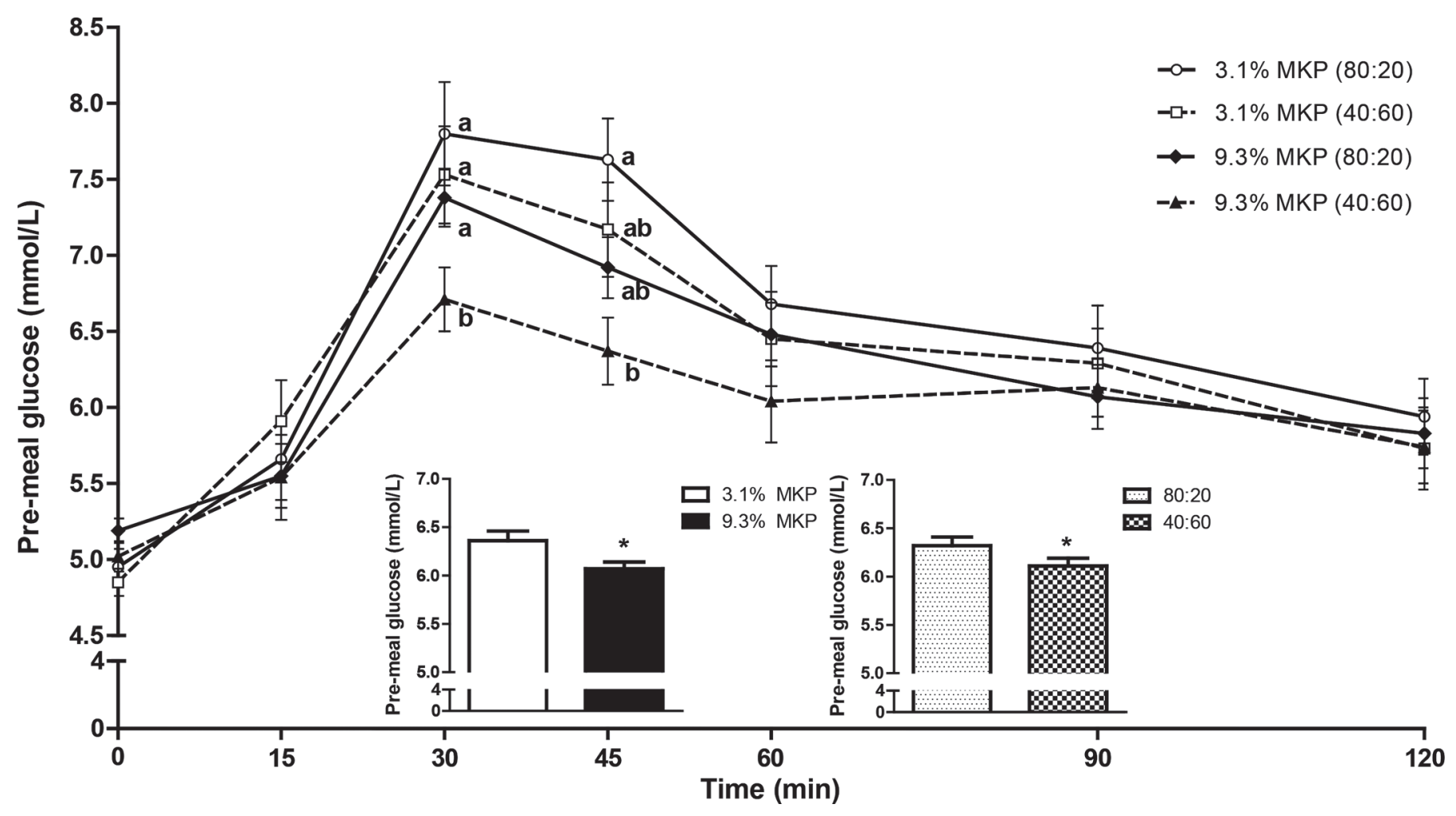

Figure 2. Effect of treatments, 3.1\% milk protein (MKP; 80 casein:20 whey protein), 3.1\% MKP (40 casein:60 whey protein), 9.3\% MKP (80 casein:20 whey protein), and 9.3\% MKP (40 casein:60 whey protein), on pre-meal glucose over time, from 0 to 120 min, after the consumption of a breakfast meal and just before the consumption of the ad libitum pizza lunch in healthy adults. Concentration, $P=0.0022$, ratio, $P$ $=0.0409$; time, $P<0.0001$; concentration $\times$ ratio, $P=0.5753$; concentration $\times$ time, $P=0.0306$; ratio $\times$ time, $P=0.2620$, by 3 -way analysis of covariance. Means with different letters $(\mathrm{a}, \mathrm{b})$ are significantly different at each measured time (1-way ANOVA, Tukey's post hoc test, $P<$ 0.05). Embedded panels show mean glucose by concentration of MKP and casein-to-whey ratio. *An asterisk indicates a statistically significant difference between treatments of different MKP and different casein-to-whey ratios. 


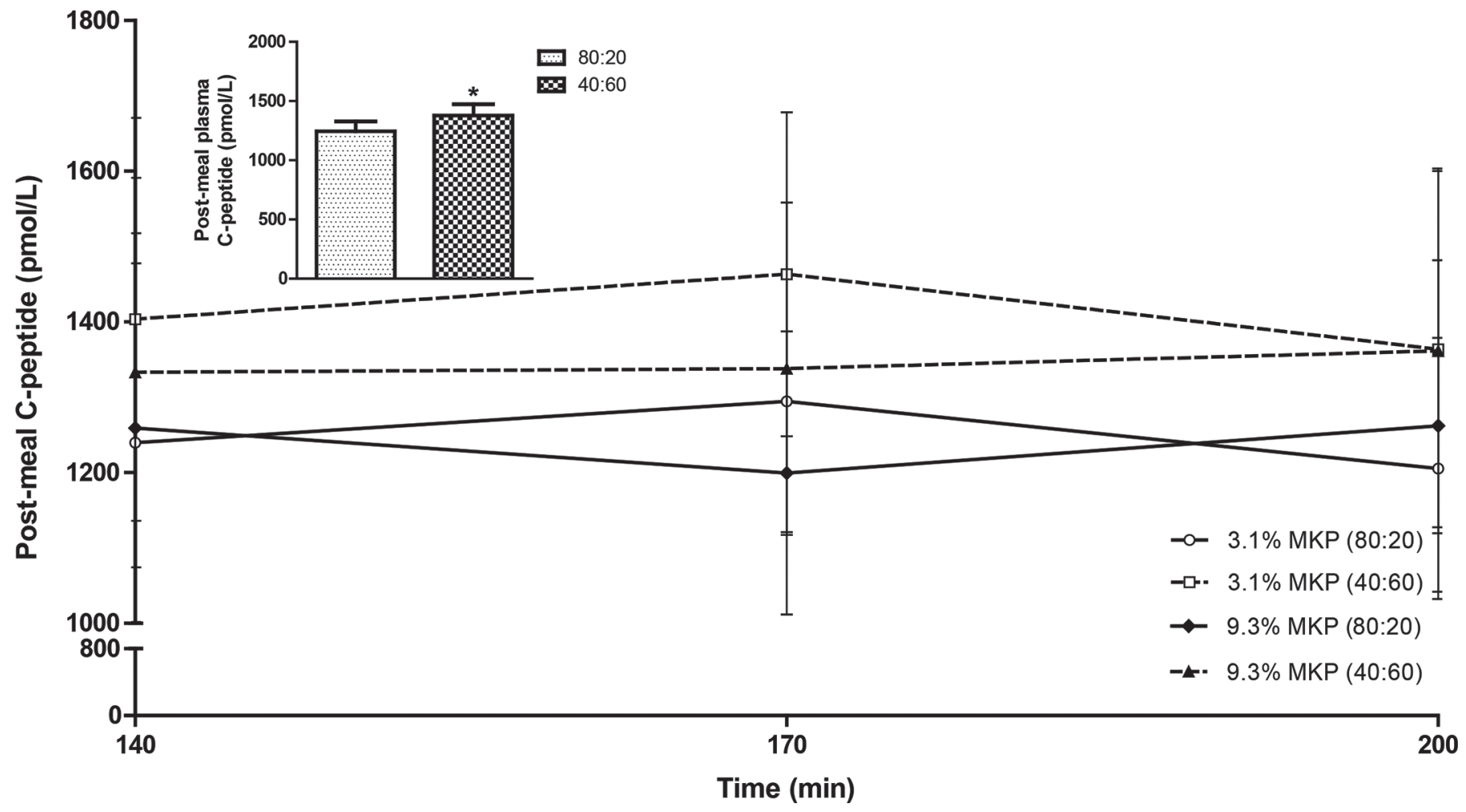

Figure 3. Effect of treatments, 3.1\% milk protein (MKP; 80 casein:20 whey protein), 3.1\% MKP (40 casein:60 whey protein), 9.3\% MKP (80 casein:20 whey protein), and 9.3\% MKP (40 casein:60 whey protein), on post-meal C-peptide over time, from 140 to 200 min, right after the consumption of the ad libitum pizza lunch in healthy adults. Concentration, $P=0.4498$; ratio, $P=0.0147$; time, $P=0.9020$; concentration $\times$ ratio, $P=0.5319$; concentration $\times$ time, $P=0.4849$; ratio $\times$ time, $P=0.9517$, by 3 -way ANOVA. All values are mean $\pm \mathrm{SEM}, \mathrm{n}=12$. Embedded panel shows mean C-peptide by casein-to-whey ratio. *An asterisk indicates a statistically significant difference between treatments of different casein-to-whey ratios.

\section{DISCUSSION}

The hypothesis that the amount of milk protein, and to a lesser extent the casein-to-whey ratio, of milk beverages affect post-consumption responses of blood glucose and glucoregulatory and appetite hormones is supported by several findings from this study: (1) blood glucose responses were lower after consumption of $9.3 \%$ milk protein compared with $3.1 \%$ milk protein, during the entire post-meal period and during the pre-lunch period. In particular, the milk with increased protein content (9.3\% milk protein) and reduced casein-to-whey ratio (40:60) resulted in lower peak glucose responses in the pre-meal period, at 30 and $45 \mathrm{~min}$; (2) these beneficial effects on blood glucose were not explained by insulin-dependent mechanisms, because insulin and C-peptide responses did not differ among treatments; (3) these responses were explained by insulin-independent mechanisms, including delayed gastric emptying. In fact, the milk with increased protein content (9.3\%) resulted in higher GLP-1 responses in the total and pre-meal periods, higher CCK levels in the pre-meal period and lower paracetamol concentrations in the total, pre-meal and within-meal periods. In addition, mean plasma ghrelin levels were lower after treatments with lower casein-to-whey ratio 40:60, compared with 80:20 ratio, during the lunch meal and in the post-meal period.

The beneficial effect for blood glucose of increased protein content of milk is consistent with other reports that proteins in general (Gannon et al., 1988; Karamanlis et al., 2007) and milk proteins specifically (Frid et al., 2005; Petersen et al., 2009) reduce glycemic response compared with carbohydrate alone. Dairy proteins have been shown to attenuate postprandial hyperglycemia and prevent impairments in vascular endothelial function in adults with prediabetes (McDonald et al., 2019a,b). Several studies from our laboratory have reported improved glycemic regulation following the consumption of different forms of dairy products, before or during an ad libitum meal (Panahi et al., 2013a,b; El Khoury et al., 2014a,b) or with a high glycemic carbohydrate at a breakfast meal (Law et al., 2017a,b). This effect has been attributed to milk 
proteins (Luhovyy et al., 2007; Akhavan et al., 2009), and more specifically to whey protein (Jakubowicz and Froy, 2013).

The milks with increased protein content and the milks with decreased casein-to-whey ratio resulted in lower glucose peaks than the other milks during the pre-meal period. At glucose peak time $(30 \mathrm{~min})$ in particular, mean glucose peak levels were significantly lower following consumption of milk with reduced casein-to-whey ratio (40:60) versus milk with a regular ratio (80:20; $P=0.0021)$. These findings are consistent with the known effects of whey proteins on metabolic control. Observations in animal models and in humans show that whey is efficacious for glycemic control. Increasing the dietary protein-to-carbohydrate ratio with whey protein isolate (40\%) reduced plasma glucose levels in mice fed a high-fat diet (McAllan et al., 2014). Improvements in glucose tolerance tested in obese rats fed whey, casein, or whey plus casein were greater in rats fed whey than in rats fed whey plus casein (Nilsson et al., 2007; Pezeshki et al., 2015). As well, $50 \mathrm{~g}$ of whey protein in a meal lowered glycemia more than a similar amount of protein from turkey or egg albumin over 240 min in lean men (Pal and Ellis, 2010). Even in people with type 2 diabetes, $55 \mathrm{~g}$ of whey isolate consumed orally as a preload to or co-ingested with a carbohydrate meal has been shown to slow gastric emptying and reduce the glycemic response to the meal (Ma et al., 2009). To our knowledge, no studies have compared the metabolic effects of human milk or infant formulas to those of cow milk, despite their different casein-towhey ratios. However, human milk (which has a high casein-to-whey ratio) and a typical infant formula (with a low casein-to-whey ratio and a higher protein content) elicited similar postprandial glycemic and insulinemic responses in healthy breastfeeding mothers (Wright et al., 2015). In that study, the protein-to-carbohydrate ratios in the milk and formula averaged 1:6, as in the low-protein milks in the current study, which also failed to show an effect of ratio, which was apparent only in the high-protein milks with the high ratio.

Insulin was not higher after consumption of the high-protein milks, in contrast with the suggestion that lower glucose is due to a rise in blood insulin stimu-

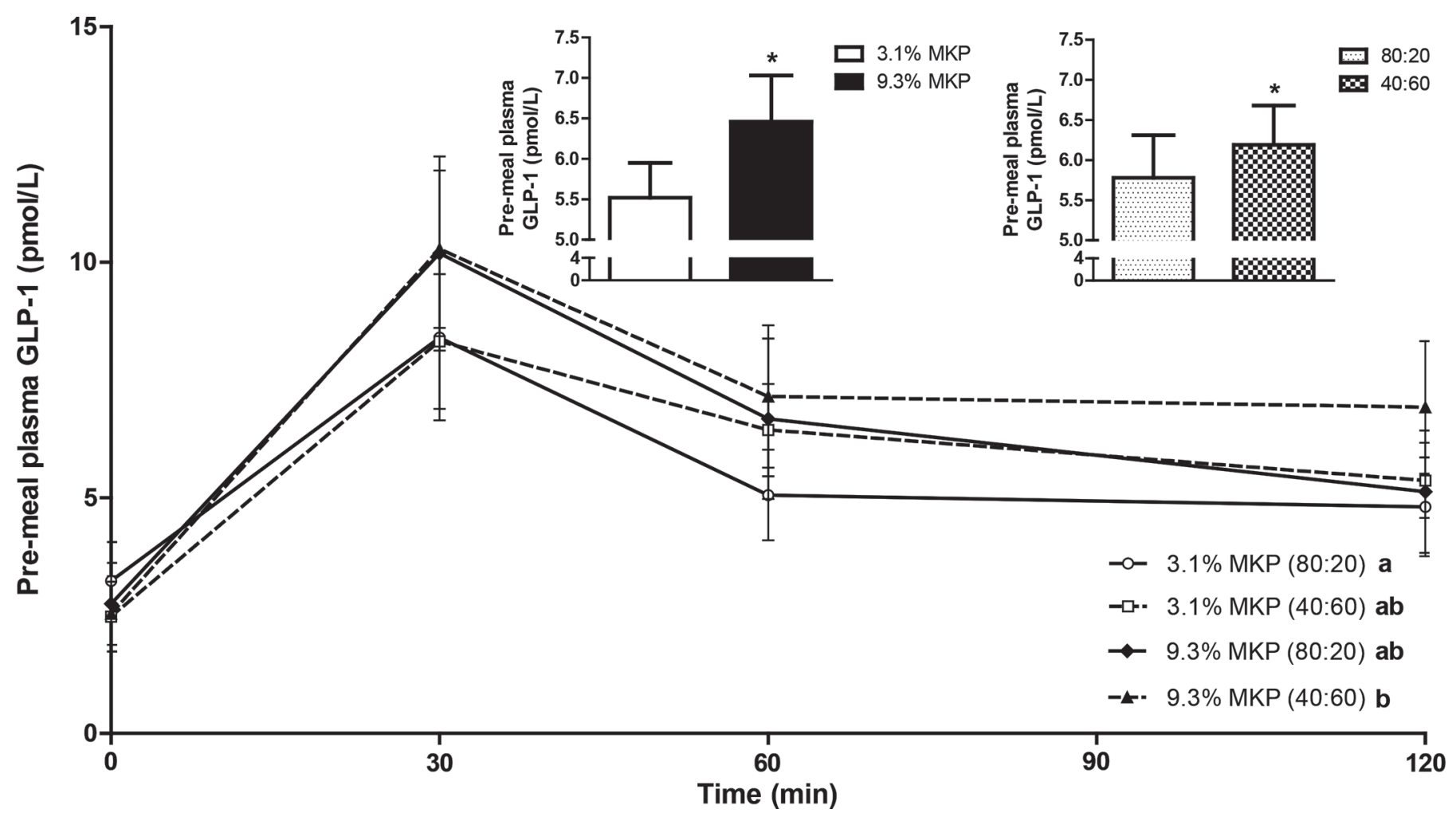

Figure 4. Effect of treatments, 3.1\% milk protein (MKP; 80 casein:20 whey protein), 3.1\% MKP (40 casein:60 whey protein), 9.3\% MKP (80 casein:20 whey protein), and 9.3\% MKP (40 casein:60 whey protein), on pre-meal glucagon-like peptide 1 (GLP-1) over time, from 0 to 120 min, after the consumption of a breakfast meal and just before the consumption of the ad libitum pizza lunch in healthy adults. Concentration, $P=0.0075$, ratio, $P=0.0245$; time, $P<0.001$; concentration $\times$ ratio, $P=0.6214$; concentration $\times$ time, $P=0.2492 ;$ ratio $\times$ time, $P=0.3436$, by 3 -way analysis of covariance. All values are mean \pm SEM, $\mathrm{n}=12$. Different letters indicate a significant difference, $P<0.05$, by Tukey's post hoc test. Embedded panels show mean GLP-1 by concentration of MKP and casein-to-whey ratio. *An asterisk indicates a statistically significant difference between treatments of different MKP and different casein-to-whey ratios. 
lated by branched-chain amino acids (Anderson et al., 2011). In lean men, the intraduodenal infusion of hydrolyzed whey protein alone stimulated insulin and glucagon release in a load-dependent fashion, associated with a modest reduction in blood glucose (Ryan et al., 2012). In another study on lean individuals, the oral ingestion of $18 \mathrm{~g}$ of intact whey protein with $25 \mathrm{~g}$ of glucose increased insulin release and reduced blood glucose compared with $25 \mathrm{~g}$ of glucose alone (Ryan et al., 2013). In the present study, the lower postprandial glucose concentrations reported after consumption of beverages with increased milk protein content and reduced casein-to-whey ratio consumed with $77 \mathrm{~g}$ of carbohydrate cannot be attributed to increased insulin secretion for 2 reasons. First, we found no differences in insulin concentrations by treatment. Second, postprandial levels of C-peptide were not affected by protein concentration; C-peptide is the part of proinsulin that is cleaved before co-secretion with insulin from the pancreatic $\beta$ cells, so it is produced in equimolar amounts to endogenous insulin (Leighton et al., 2017). These findings support previous studies showing that modulation of postprandial glycemia by milk proteins is through insulin-independent mechanisms (Akhavan et al., 2014; Panahi et al., 2014). Others have reported that reduced glycemia after protein consumption, with carbohydrates (Karamanlis et al., 2007) or alone (Boirie et al., 1997; Hall et al., 2003), is not solely due to increased insulin release, but may also be related to the release of gut hormones that delay stomach emptying or to the release of incretins that increase the efficacy of insulin (Jakubowicz and Froy, 2013).

In this study, the treatment effects that might explain the decrease in postprandial glycemia may be responses in GLP-1 and stomach emptying as measured by the paracetamol appearance in blood. In the premeal periods, we found increased GLP-1 concentrations following consumption of milk beverages with increased protein content, and blood glucose was negatively correlated with GLP-1. Previous studies have shown increased GLP-1 (Akhavan et al., 2010, 2014; Ryan et al., 2012) and delayed stomach emptying (Ma et al., 2009; Akhavan et al., 2014) in response to whey protein consumption. Compared to casein, gluten and

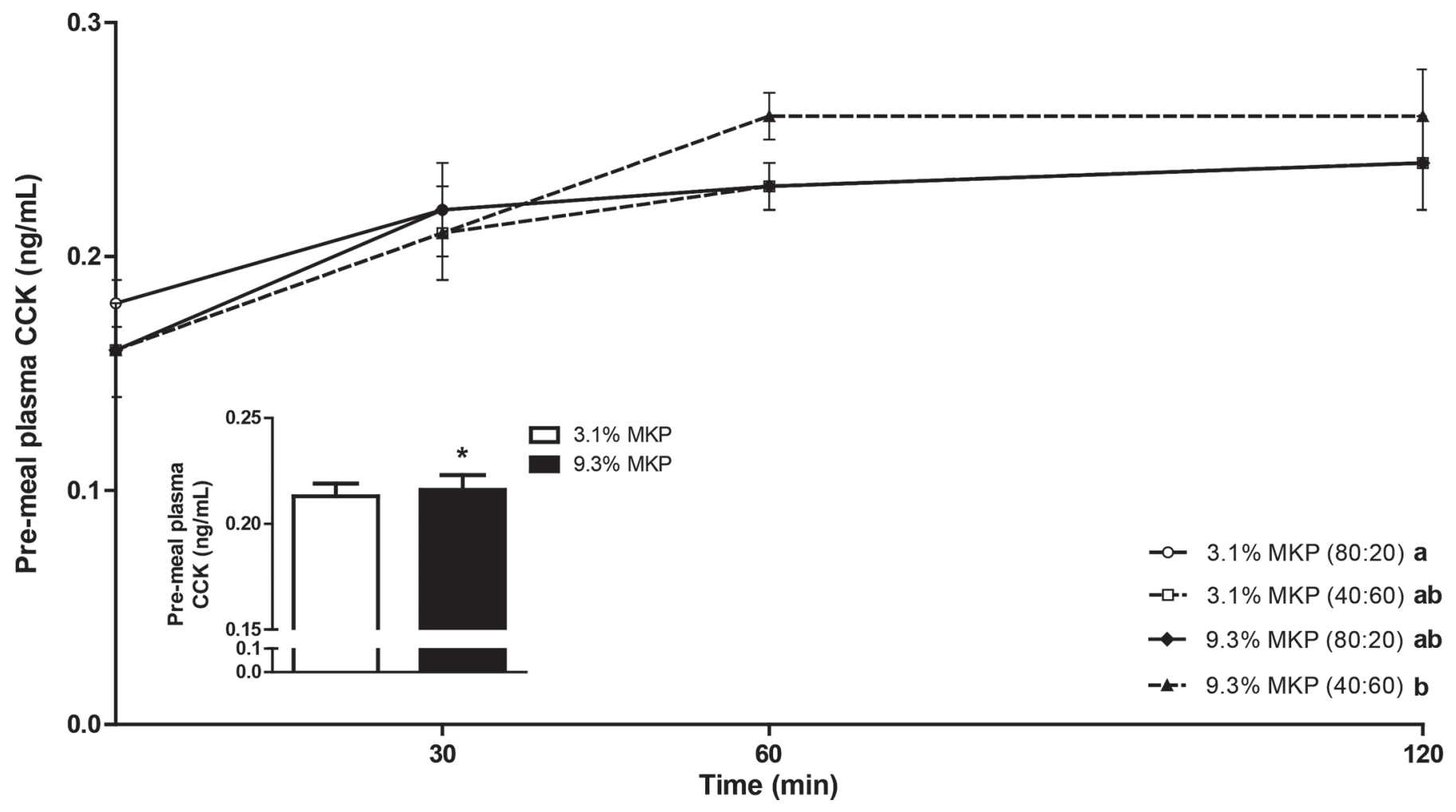

Figure 5. Effect of treatments, 3.1\% milk protein (MKP; 80 casein:20 whey protein), 3.1\% MKP (40 casein:60 whey protein), 9.3\% MKP (80 casein:20 whey protein), and 9.3\% MKP (40 casein:60 whey protein) on pre-meal cholecystokinin (CCK) over time, from 0 to 120 min, after the consumption of a breakfast meal and just before the consumption of the ad libitum pizza lunch in healthy adults. Concentration, $P=$ 0.0443 ; ratio, $P=0.0617$; time, $P<0.0001$; concentration $\times$ ratio, $P=0.6439$; concentration $\times$ time, $P=0.3102 ;$ ratio $\times$ time, $P=0.0796$, by 3 -way analysis of covariance. All values are mean \pm SEM, $\mathrm{n}=12$. Different letters indicate a significant difference, $P<0.05$, by Tukey's post hoc test. Embedded panel shows mean CCK by concentration of MKP. *An asterisk indicates a statistically significant difference between treatments of different MKP. 


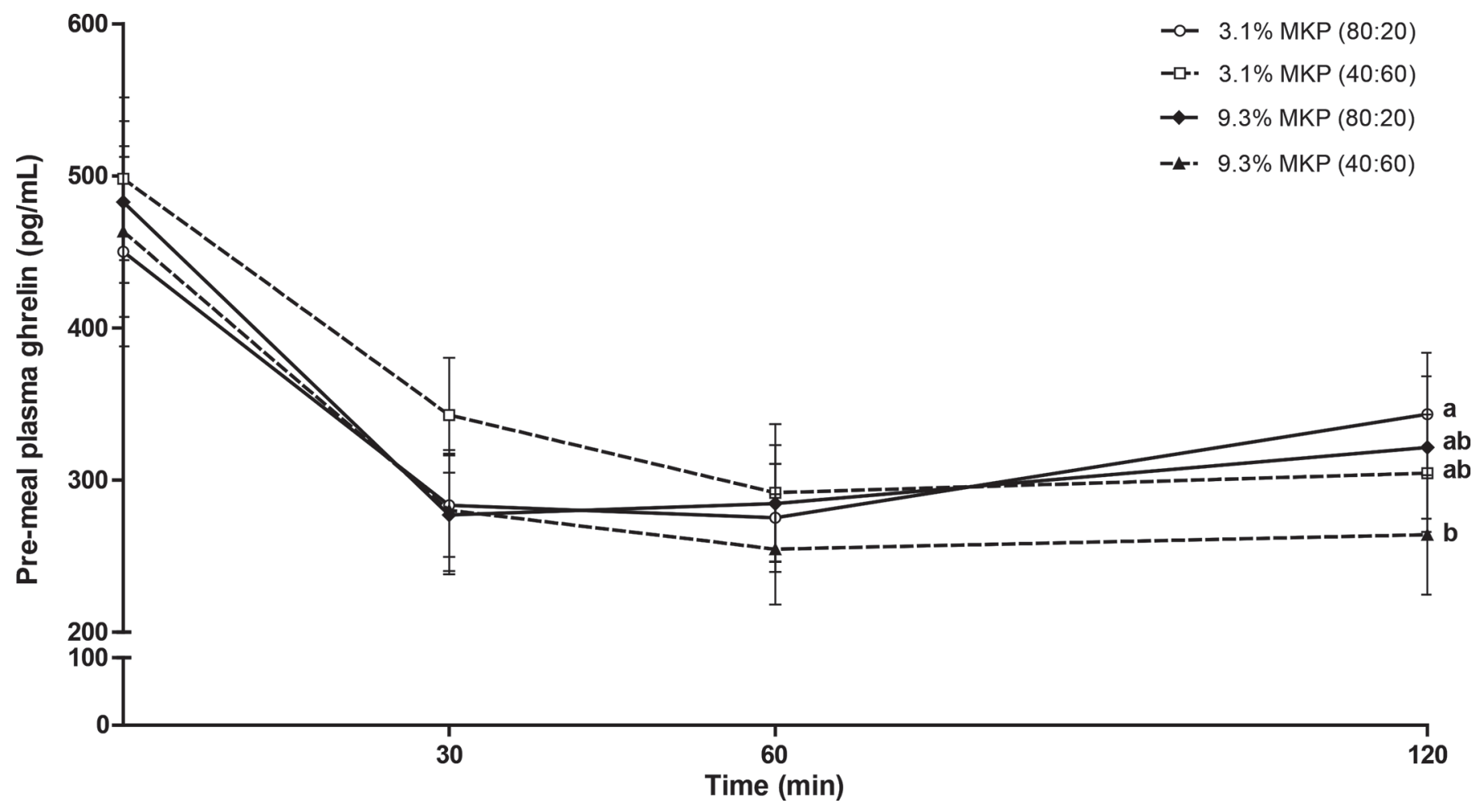

Figure 6. Effect of treatments, 3.1\% milk protein (MKP; 80 casein:20 whey protein), 3.1\% MKP (40 casein:60 whey protein), 9.3\% MKP (80 casein:20 whey protein), and 9.3\% MKP (40 casein:60 whey protein), on pre-meal ghrelin over time, from 0 to 120 min, after the consumption of a breakfast meal and just before the consumption of the ad libitum pizza lunch in healthy adults. Concentration, $P=0.0690 ;$ ratio, $P=$ 0.2888 ; time, $P<0.0001$; concentration $\times$ ratio, $P=0.7054$; concentration $\times$ time, $P=0.5885$; ratio $\times$ time, $P=0.0388$, by 3 -way analysis of covariance. Means with different letters $(\mathrm{a}, \mathrm{b})$ are significantly different at each measured time (1-way ANOVA, Tukey's post hoc test, $P<0.05)$.

fish protein, whey isolate decreased the rate of gastric emptying in obese people without diabetes (Stanstrup et al., 2014). In mice with insulin resistance induced by a high-fat diet, GLP-1 improved hepatic insulin sensitivity (Khound et al., 2017). In addition, GLP-1 slows gastric emptying by crossing the blood-brain barrier and directly transmitting signals that inhibit gastric emptying (Nauck et al., 1997). We found a negative correlation for paracetamol with areas under the curve for GLP-1 and insulin levels throughout the postprandial period. Paracetamol responses were lower after the milks with high protein $(9.3 \%)$ compared with those with regular protein $(3.1 \%)$ concentrations during the pre-meal and total time periods. As well, at glucose peak time $(30 \mathrm{~min})$ paracetamol mean absolute levels were lower after consumption of milks with 40:60 casein-towhey compared to those with 80:20 ratios $(P=0.0358)$, in parallel to the reported lower mean glucose peak levels. In healthy individuals, the rate of gastric emptying acts as a major factor in blood glucose homeostasis by controlling the delivery of carbohydrate to the small intestine (Horowitz et al., 1993). Although correlations cannot show cause and effect, many of the associations among the hormonal responses, including PYY,
CCK, and ghrelin, in addition to GLP-1 and insulin, participate in feedback loops that affect stomach emptying (Panahi et al., 2014). Other studies have revealed additional potential insulin-independent mechanisms of action of milk protein, particularly whey protein, on glucose responses that have not been explored in the current study. A rodent study by Nilaweera and colleagues (2017) has shown decreased gene expression of glucose transporter 2 and altered gut microbiota composition with the consumption of whey protein isolate, associated with reduced energy absorption through the intestine; together, these mechanisms may be linked to lower blood glucose levels reported with whey protein.

Although we expected the sample size to be insufficient to show treatment effects for subjective appetite and food intake, we did report an absence of treatment effects on appetite and food intake for the complete sample of 32 (Kung et al., 2018), and such effects may have been compromised by stomach discomfort reported because of the high lactose content of the treatments. Nevertheless, this finding was surprising, because appetite regulatory hormones were strongly affected by the treatments and showed coordinated responses that would be expected to decrease food intake. 
Table 5. Significant correlations (r) between dependent pre- and post-meal means ${ }^{1}$

\begin{tabular}{|c|c|c|c|c|c|c|c|c|}
\hline Dependent variable ${ }^{2}$ & $\begin{array}{c}\text { Subjective } \\
\text { appetite }(\mathrm{mm})\end{array}$ & $\begin{array}{l}\text { Glucose } \\
(\mathrm{mmol} / \mathrm{L})\end{array}$ & $\begin{array}{l}\text { Insulin } \\
(\mu \mathrm{IU} / \mathrm{mL})\end{array}$ & $\begin{array}{l}\text { C-peptide } \\
(\mathrm{pmol} / \mathrm{L})\end{array}$ & $\begin{array}{l}\text { GLP-1 } \\
(\mathrm{pmol} / \mathrm{L})\end{array}$ & $\begin{array}{c}\text { PYY } \\
(\mathrm{pg} / \mathrm{mL})\end{array}$ & $\begin{array}{c}\text { CCK } \\
(\mathrm{ng} / \mathrm{mL})\end{array}$ & $\begin{array}{c}\text { Ghrelin } \\
(\mathrm{pg} / \mathrm{mL})\end{array}$ \\
\hline \multicolumn{9}{|l|}{ Pre-meal (0-120 min) } \\
\hline Subjective appetite $(\mathrm{mm})$ & - & & & & & & & \\
\hline Insulin $(\mu \mathrm{IU} / \mathrm{mL})$ & -0.36 & NS & - & & & & & \\
\hline C-peptide (pmol/L) & NS & NS & 0.60 & - & & & & \\
\hline GLP-1 (pmol /L) & NS & -0.32 & NS & NS & - & & & \\
\hline Ghrelin $(\mathrm{pg} / \mathrm{mL})$ & NS & NS & -0.57 & NS & NS & NS & NS & - \\
\hline Paracetamol $(\mathrm{mmol} / \mathrm{L})$ & NS & NS & -0.32 & NS & NS & NS & -0.30 & NS \\
\hline \multicolumn{9}{|l|}{ Post-meal (140-200 min) } \\
\hline Subjective appetite $(\mathrm{mm})$ & - & & & & & & & \\
\hline Glucose $(\mathrm{mmol} / \mathrm{L})$ & 0.32 & - & & & & & & \\
\hline Insulin $(\mu \mathrm{IU} / \mathrm{mL})^{\prime}$ & 0.38 & 0.63 & - & & & & & \\
\hline C-peptide (pmol/L) & NS & 0.54 & 0.67 & - & & & & \\
\hline
\end{tabular}

${ }^{1}$ Correlation coefficients (r) indicate significant differences between dependent measures, $P<0.05$.

${ }^{2}$ GLP-1 = glucagon-like peptide 1 ; PYY = peptide tyrosine-tyrosine; CCK = cholecystokinin.

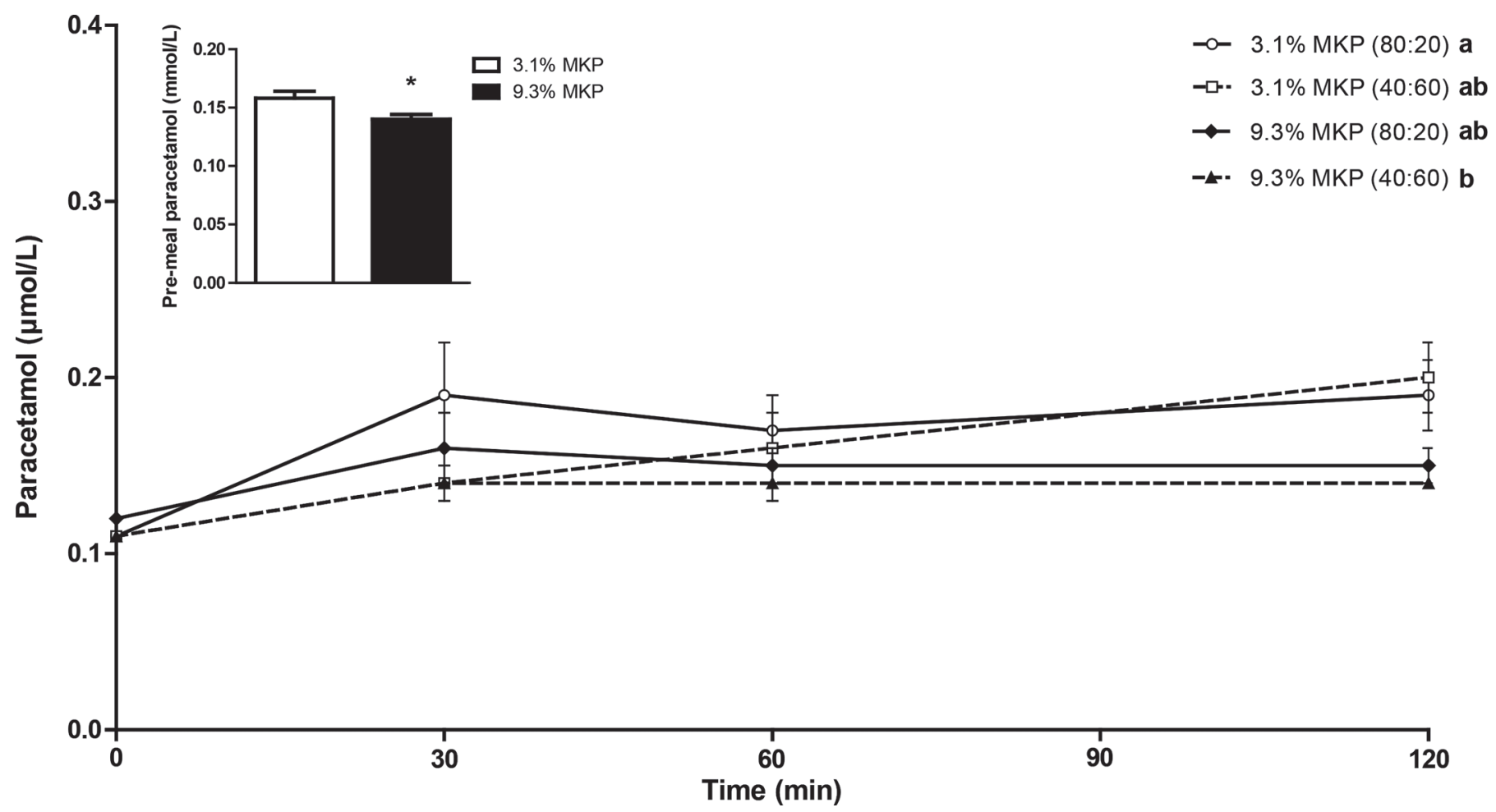

Figure 7. Effect of treatments, 3.1\% milk protein (MKP; 80 casein:20 whey protein), 3.1\% MKP (40 casein:60 whey protein), 9.3\% MKP (80 casein:20 whey protein), and 9.3\% MKP (40 casein:60 whey protein), on pre-meal paracetamol over time, from 0 to 120 min, after the consumption of a breakfast meal and just before the consumption of the ad libitum pizza lunch in healthy adults. Concentration, $P=0.0135$; ratio, $P=0.1203$; time, $P<0.0001$; concentration $\times$ ratio, $P=0.9190$; concentration $\times$ time, $P=0.1139 ;$ ratio $\times$ time, $P=0.1552$, by 3 -way analysis of covariance. All values are mean \pm SEM, $\mathrm{n}=12$. Different letters indicate a significant difference, $P<0.05$, by Tukey's post hoc test. Embedded panel shows mean paracetamol by concentration of MKP. *An asterisk indicates a statistically significant difference between treatments of different MKP. 
In the present study, pre-meal glucose was lowest following consumption of the milk with $9.3 \%$ milk protein and 40:60 casein-to-whey ratio-significantly at 30 and 45 min-whereas post-meal glucose was lowest after consumption of the milk with $9.3 \%$ milk protein and 80:20 casein-to-whey ratio, without reaching statistical significance (Figure 1). Although these results are difficult to explain, they emphasize the importance of the casein-to-whey ratio.

This study had some limitations. First, we did not control for menstrual cycle in women, a factor that is known to affect appetite and food intake (Buffenstein et al., 1995). Second, the sample size was too small for meaningful comparisons between men and women. Third, this study assessed only the acute and short-term effects of these beverages in healthy young men and women. Thus, their application to those with insulin resistance and on long-term glycemic control is unclear. However, the results of this study add to accumulating evidence that dairy protein quantity and composition has the potential to aid in the dietary management of obesity and type 2 diabetes mellitus (Jakubowicz and Froy, 2013).

When consumed with carbohydrate, milk beverages with increased protein content and, to a lesser extent, decreased casein-to-whey ratio, lower postprandial glucose response through insulin-independent mechanisms in healthy adult men and women.

\section{ACKNOWLEDGMENTS}

The authors thank Yurie Yamagishi for her technical contributions and all study participants and graduate and undergraduate students who assisted with this research. This study was supported by a contribution from the Dairy Research Cluster Initiative (Dairy Farmers of Canada, Agriculture and Agri-Food Canada, and the Canadian Dairy Commission). The funders had no role in the study design, data collection and analysis, decision to publish, or preparation of the manuscript.

\section{REFERENCES}

Akhavan, T., B. L. Luhovyy, P. H. Brown, C. E. Cho, and G. H. Anderson. 2010. Effect of premeal consumption of whey protein and its hydrolysate on food intake and postmeal glycemia and insulin responses in young adults. Am. J. Clin. Nutr. 91:966-975.

Akhavan, T., B. L. Luhovyy, S. Panahi, R. Kubant, P. H. Brown, and G. H. Anderson. 2014. Mechanism of action of pre-meal consumption of whey protein on glycemic control in young adults. J. Nutr. Biochem. 25:36-43.

Akhavan, T., S. Panahi, G. H. Anderson, and B. L. Luhovyy. 2009. Application of dairy-derived ingredients in food intake and metabolic regulation. Pages 212-237 in Dairy-Derived Ingredients: Food and Nutraceutical Uses. M. Corredig, ed. Woodhead Publishing Ltd., Cambridge, UK.
Anderson, G. H., Y. Liu, C. E. Smith, T. T. Liu, M. F. Nunez, R. C. Mollard, and B. L. Luhovyy. 2014. The acute effect of commercially available pulse powders on postprandial glycaemic response in healthy young men. Br. J. Nutr. 112:1966-1973.

Anderson, G. H., B. Luhovyy, T. Akhavan, and S. Panahi. 2011. Milk proteins in the regulation of body weight, satiety, food intake and glycemia. Nestle Nutr. Workshop Ser. Pediatr. Program. 67:147159.

Anderson, G. H., and S. E. Moore. 2004. Dietary proteins in the regulation of food intake and body weight in humans. J. Nutr. 134:974S-979S.

Boirie, Y., M. Dangin, P. Gachon, M. P. Vasson, J. L. Maubois, and B. Beaufrere. 1997. Slow and fast dietary proteins differently modulate postprandial protein accretion. Proc. Natl. Acad. Sci. USA 94:14930-14935.

Buffenstein, R., S. D. Poppitt, R. M. McDevitt, and A. M. Prentice. 1995. Food intake and the menstrual cycle: A retrospective analysis, with implications for appetite research. Physiol. Behav. 58:1067-1077.

Chen, M., Q. Sun, E. Giovannucci, D. Mozaffarian, J. E. Manson, W. C. Willett, and F. B. Hu. 2014. Dairy consumption and risk of type 2 diabetes: 3 cohorts of US adults and an updated metaanalysis. BMC Med. 12:215.

Dangin, M., Y. Boirie, C. Garcia-Rodenas, P. Gachon, J. Fauquant, P. Callier, O. Ballèvre, and B. Beaufrère. 2001. The digestion rate of protein is an independent regulating factor of postprandial protein retention. Am. J. Physiol. Endocrinol. Metab. 280:E340-E348.

El Khoury, D., P. Brown, G. Smith, S. Berengut, S. Panahi, R. Kubant, and G. H. Anderson. 2014b. Increasing the protein to carbohydrate ratio in yogurts consumed as a snack reduces post-consumption glycemia independent of insulin. Clin. Nutr. 33:29-38.

El Khoury, D., H. D. Goff, S. Berengut, R. Kubant, and G. H. Anderson. 2014a. Effect of sodium alginate addition to chocolate milk on glycemia, insulin, appetite and food intake in healthy adult men. Eur. J. Clin. Nutr. 68:613-618.

Erber, E., B. N. Hopping, A. Grandinetti, S. Y. Park, L. N. Kolonel, and G. Maskarinec. 2010. Dietary patterns and risk for diabetes: The multiethnic cohort. Diabetes Care 33:532-538.

Eussen, S. J., M. C. van Dongen, N. Wijckmans, L. den Biggelaar, S. J. Oude Elferink, C. M. Singh-Povel, M. T. Schram, S. J. Sep, C. J. van der Kallen, A. Koster, N. Schaper, R. M. Henry, C. D. Stehouwer, and P. C. Dagnelie. 2016. Consumption of dairy foods in relation to impaired glucose metabolism and type 2 diabetes mellitus: The Maastricht Study. Br. J. Nutr. 115:1453-1461.

Faul, F., E. Erdfelder, A.-G. Lang, and A. Buchner. 2007. G*Power 3 : A flexible statistical power analysis program for the social, behavioral, and biomedical sciences. Behav. Res. Methods 39:175-191.

Fox, P. F., and P. L. H. McSweeney. 1998. Dairy Chemistry and Biochemistry. Blackie Academic \& Professional, London, UK.

Frid, A. H., M. Nilsson, J. J. Holst, and I. M. Bjorck. 2005. Effect of whey on blood glucose and insulin responses to composite breakfast and lunch meals in type 2 diabetic subjects. Am. J. Clin. Nutr. 82:69-75.

Gannon, M. C., F. Q. Nuttall, B. J. Neil, and S. A. Westphal. 1988. The insulin and glucose responses to meals of glucose plus various proteins in type II diabetic subjects. Metabolism 37:1081-1088.

Guyonnet, D., B. Naliboff, P. Rondeau, E. Mayer, and O. Chassany. 2013. Gastrointestinal well-being in subjects reporting mild gastrointestinal discomfort: Characteristics and properties of a global assessment measure. Br. J. Nutr. 110:1263-1271.

Hall, W. L., D. J. Millward, S. J. Long, and L. M. Morgan. 2003. Casein and whey exert different effects on plasma amino acid profiles, gastrointestinal hormone secretion and appetite. Br. J. Nutr. 89:239-248.

Hirahatake, K. M., J. L. Slavin, K. C. Maki, and S. H. Adams. 2014. Associations between dairy foods, diabetes, and metabolic health: Potential mechanisms and future directions. Metabolism 63:618627.

Horowitz, M., M. A. Edelbroek, J. M. Wishart, and J. W. Straathof. 1993. Relationship between oral glucose tolerance and gastric emptying in normal healthy subjects. Diabetologia 36:857-862. 
Jahan-Mihan, A., B. L. Luhovyy, D. El Khoury, and G. H. Anderson. 2011. Dietary proteins as determinants of metabolic and physiologic functions of the gastrointestinal tract. Nutrients 3:574-603.

Jakubowicz, D., and O. Froy. 2013. Biochemical and metabolic mechanisms by which dietary whey protein may combat obesity and type 2 diabetes. J. Nutr. Biochem. 24:1-5.

Karamanlis, A., R. Chaikomin, S. Doran, M. Bellon, F. D. Bartholomeusz, J. M. Wishart, K. L. Jones, M. Horowitz, and C. K. Rayner. 2007. Effects of protein on glycemic and incretin responses and gastric emptying after oral glucose in healthy subjects. Am. J. Clin. Nutr. 86:1364-1368.

Khound, R., J. Taher, C. Baker, K. Adeli, and Q. Su. 2017. GLP-1 elicits an intrinsic gut-liver metabolic signal to ameliorate dietinduced VLDL overproduction and insulin resistance. Arterioscler. Thromb. Vasc. Biol. 37:2252-2259.

Klein, C. J. 2002. Nutrient requirements for preterm infant formulas. J. Nutr. 132:1395S-577S.

Kung, B., G. H. Anderson, S. Paré, A. J. Tucker, A. J. Wright, and H. D. Goff. 2018. Effect of milk protein intake and casein:whey ratio in breakfast meals on postprandial glucose, satiety ratings and subsequent meal intake. J. Dairy Sci. 101:8688-8701.

Law, M., P. S. P. Huot, Y. T. Lee, S. Vien, B. L. Luhovyy, and G. H. Anderson. 2017a. The effect of dairy and nondairy beverages consumed with high glycemic cereal on subjective appetite, food intake, and postprandial glycemia in young adults. Appl. Physiol. Nutr. Metab. 42:1201-1209.

Law, M., Y. T. Lee, S. Vien, B. L. Luhovyy, and G. H. Anderson. 2017b. The effect of dairy products consumed with high glycemic carbohydrate on subjective appetite, food intake, and postprandial glycemia in older adults. Appl. Physiol. Nutr. Metab. 42:1210-1216.

Leighton, E., C. A. Sainsbury, and G. C. Jones. 2017. A practical review of C-peptide testing in diabetes. Diabetes Ther. 8:475-487.

Luhovyy, B. L., T. Akhavan, and G. H. Anderson. 2007. Whey proteins in the regulation of food intake and satiety. J. Am. Coll. Nutr. 26:704S-712S.

Ma, J., J. E. Stevens, K. Cukier, A. F. Maddox, J. M. Wishart, K. L. Jones, P. M. Clifton, M. Horowitz, and C. K. Rayner. 2009. Effects of a protein preload on gastric emptying, glycemia, and gut hormones after a carbohydrate meal in diet-controlled type 2 diabetes. Diabetes Care 32:1600-1602.

Martin, C. R., P. R. Ling, and G. L. Blackburn. 2016. Review of infant feeding: key features of breast milk and infant formula. Nutrients 8:E279.

McAllan, L., P. Skuse, P. D. Cotter, P. O'Connor, J. F. Cryan, R. P. Ross, G. Fitzgerald, H. M. Roche, and K. N. Nilaweera. 2014. Protein quality and the protein to carbohydrate ratio within a high fat diet influences energy balance and the gut microbiota in C57BL/6J mice. PLoS One 9:e88904.

McDonald, J. D., E. Mah, C. Chitchumroonchokchai, P. Dey, A. N. Labyk, F. A. Villamena, J. S. Volek, and R. S. Bruno. 2019b. Dairy milk proteins attenuate hyperglycemia-induced impairments in vascular endothelial function in adults with prediabetes by limiting increases in glycemia and oxidative stress that reduce nitric oxide bioavailability. J. Nutr. Biochem. 63:165-176.

McDonald, J. D., E. Mah, P. Dey, B. D. Olmstead, G. Y. Sasaki, F. A. Villamena, and R. S. Bruno. 2019a. Dairy milk, regardless of fat content, protects against postprandial hyperglycemia-mediated impairments in vascular endothelial function in adults with prediabetes by limiting oxidative stress responses that reduce nitric oxide bioavailability. J. Nutr. Biochem. 63:129-139.

Nauck, M. A., U. Niedereichholz, R. Ettler, J. J. Holst, C. Orskov, R. Ritzel, and W. H. Schmiegel. 1997. Glucagon-like peptide 1 inhibition of gastric emptying outweighs its insulinotropic effects in healthy humans. Am. J. Physiol. 273:E981-E988.

Nilaweera, K. N., R. Cabrera-Rubio, J. R. Speakman, P. M. O'Connor, A. McAuliffe, C. M. Guinane, E. M. Lawton, F. Crispie, M. Aguilera, M. Stanley, S. Boscaini, S. Joyce, S. Melgar, J. F. Cryan, and P. D. Cotter. 2017. Whey protein effects on energy balance link the intestinal mechanisms of energy absorption with adiposity and hypothalamic neuropeptide gene expression. Am. J. Physiol. Endocrinol. Metab. 313:E1-E11.

Nilsson, M., J. J. Holst, and I. M. E. Bjorck. 2007. Metabolic effects of amino acid mixtures and whey protein in healthy subjects: Studies using glucoseequivalent drinks. Am. J. Clin. Nutr. 85:996-1004.

Pal, S., and V. Ellis. 2010. The acute effects of four protein meals on insulin, glucose, appetite and energy intake in lean men. Br. J. Nutr. 104:1241-1248.

Panahi, S., D. El Khoury, R. Kubant, T. Akhavan, B. L. Luhovyy, H. D. Goff, and G. H. Anderson. 2014. Mechanism of action of whole milk and its components on glycemic control in healthy young men. J. Nutr. Biochem. 25:1124-1131.

Panahi, S., D. El Khoury, B. L. Luhovyy, H. D. Goff, and G. H. Anderson. 2013b. Caloric beverages consumed freely at meal-time add calories to an ad libitum meal. Appetite 65:75-82.

Panahi, S., B. L. Luhovyy, T. T. Liu, T. Akhavan, D. El Khoury, H. D. Goff, and G. H. Anderson. 2013a. Energy and macronutrient content of familiar beverages interact with pre-meal intervals to determine later food intake, appetite and glycemic response in young adults. Appetite 60:154-161.

Pasiakos, S. M. 2015. Metabolic advantages of higher protein diets and benefits of dairy foods on weight management, glycemic regulation, and bone. J. Food Sci. 80:A2-A7.

Petersen, B. L., L. S. Ward, E. D. Bastian, A. L. Jenkins, J. Campbell, and V. Vuksan. 2009. A whey protein supplement decreases postprandial glycemia. Nutr. J. 8:47.

Pezeshki, A., A. Fahim, and P. K. Chelikani. 2015. Dietary whey and casein differentially affect energy balance, gut hormones, glucose metabolism, and taste preference in diet-induced obese rats. J. Nutr. 145:2236-2244

Poortvliet, P. C., S. Bérubé-Parent, V. Drapeau, B. Lamarche, J. E. Blundell, and A. Tremblay. 2007. Effects of a healthy meal course on spontaneous energy intake, satiety and palatability. Br. J. Nutr. 97:584-590.

Ryan, A. T., C. Feinle-Bisset, A. Kallas, J. M. Wishart, P. M. Clifton, M. Horowitz, and N. D. Luscombe-Marsh. 2012. Intraduodenal protein modulates antropyloroduodenal motility, hormone release, glycemia, appetite, and energy intake in lean men. Am. J. Clin. Nutr. 96:474-482.

Ryan, A. T., N. D. Luscombe-Marsh, A. A. Saies, T. J. Little, S. Standfield, M. Horowitz, and C. Feinle-Bisset. 2013. Effects of intraduodenal lipid and protein on gut motility and hormone release, glycemia, appetite, and energy intake in lean men. Am. J. Clin. Nutr. 98:300-311.

Stanstrup, J., S. S. Schou, J. Holmer-Jensen, K. Hermansen, and L. O. Dragsted. 2014. Whey protein delays gastric emptying and suppresses plasma fatty acids and their metabolites compared to casein, gluten, and fish protein. J. Proteome Res. 13:2396-2408.

Stunkard, A. J., and S. Messick. 1985. The three-factor eating questionnaire to measure dietary restraint, disinhibition and hunger. J. Psychosom. Res. 29:71-83.

Veldhorst, M. A., A. G. Nieuwenhuizen, A. Hochstenbach-Waelen, A. J. van Vught, K. R. Westerterp, M. P. Engelen, R. J. Brummer, N. E. Deutz, and M. S. Westerterp-Plantenga. 2009. Dose-dependent satiating effect of whey relative to casein or soy. Physiol. Behav. 96:675-682.

Villegas, R., S. Liu, Y. T. Gao, G. Yang, H. Li, W. Zheng, and X. O. Shu. 2007. Prospective study of dietary carbohydrates, glycemic index, glycemic load, and incidence of type 2 diabetes mellitus in middle-aged Chinese women. Arch. Intern. Med. 167:2310-2316.

Wright, C. J., F. S. Atkinson, N. Ramalingam, A. E. Buyken, and J. C. Brand-Miller. 2015. Effects of human milk and formula on postprandial glycaemia and insulinaemia. Eur. J. Clin. Nutr. 69:939-943.

Zemel, M. B. 2004. Role of calcium and dairy products in energy partitioning and weight management. Am. J. Clin. Nutr. 79:907S-912S. 